\title{
The Salience of Traditional Moral Values: Bolsonaro's Electoral Competition Strategy on Twitter
}

\author{
Sylvia Iasulaitis ${ }^{1} \&$ Isabella Vicari $^{1}$ \\ ${ }^{1}$ Social Science Department, Universidade Federal de São Carlos, São Carlos, Brazil \\ Correspondence: Sylvia Iasulaitis, Social Science Department, Universidade Federal de São Carlos, São Carlos, SP., Rod. \\ Washington Luiz, km. 235, Brazil.
}

Received: July 30, 2021

Accepted: August 26, 2021

Available online: August 30, 2021

doi:10.11114/ijsss.v9i5.5313

URL: https://doi.org/10.11114/ijsss.v9i5.5313

\begin{abstract}
This article analyzes the electoral competition strategy adopted by the Brazilian presidential candidate Jair Bolsonaro on Twitter, supported by the saliency theory - where candidates compete by emphasizing different topics and selecting issues from a universal agenda to focus the campaign's attention and efforts. The salience Bolsonaro's winning campaign attributed to values during the 2018 presidential election. Values are attitudinal guidelines related to different social, religious, economic, and political concepts, covering various topics on views about what is desirable or undesirable in a society. The study used content analysis to explore and categorize a corpus of 809 tweets posted in the account @ jairbolsonaro. The data was mined by applying computational intelligence methods and using the public API and the Python Twint library. Four dimensions of cultural variance found in the World Values Survey were used to establish the categories: traditional values, rational-secular values, survival values, and self-expression values. The results show that the content of Bolsonaro's electoral competition strategy was based on traditional moral values and the campaign's format was developed primarily via social media.
\end{abstract}

Keywords: Brazilian elections, issues, cultural variance, salience, Twitter

\section{Introduction}

The new contemporary media ecosystem offers channels and tools for political candidates and politicians to develop communication strategies and speak directly with voters. In hybrid media systems, where old and new media are intertwined and their logics complement each other, political actors are not restricted to official communication formats or mass media and can use a variety of other channels. Thus, social media platforms have been widely used in elections, particularly the Twitter microblogging platform. This technological tool allows users to have an account, customize a profile, publish and disseminate messages that may be replicated and easily retrieved, showing important communication and informational characteristics. Twitter allows establishing digital social networks, as it facilitates the representation of social actors and connections among them. These links are potential channels for disseminating ideas and news, forming agendas, and discussing topics.

Twitter topics discussed among users and forming an agenda are not restricted to the social networks established on the platform. They reverberate in different communication channels, other social media platforms, traditional media, and voters' daily conversations.

When considering that electoral disputes are disputes between rhetoric - the winning rhetoric is the one that convinces the voters - it is possible to explain the candidates' strategies by the saliency theory, according to which candidates compete emphasizing different topics (Robertson, 1976). Campaigns select issues from a universal agenda to focus attention and efforts, and the prominence attributed to each issue distinguishes one competitor from another. These differences may be based on either political preferences or value-related positions. Values are guidelines linked to different social, religious, economic, and political concepts structuring a wide range of attitudes (Moreno \& Carballo, 2013; Inglehart \& Carballo, 2008) and referring to personal views about what is or is not desirable in a society.

Studies conducted after the 1970s have demonstrated generational changes in values based on the human development theory and empirical investigations that originated the world cultural map. The map was developed by political scientists Ronald Inglehart and Christian Welzel, inspired by the World Values Survey. According to the authors, there was a transition from materialist goals focusing on physical security toward postmaterialist goals, emphasizing aspects 
such as freedom of expression, environmental protection, human rights, minority rights (racial, gender immigrants, people with disabilities). Inglehart and Welzel (2005), and several other researchers seek to explain the process of changing values from the concept of marginal utility, based on Maslow's hierarchy of needs, studies on human emancipation, and considering Amartya Sen's approach of development as freedom.

Inglehart (1990) uses these theoretical approaches to explain that evaluative priorities - i.e., aspects to which individuals attribute subjective value and define as goals- are related to objective conditions in which such priorities are inserted. Thus, in an environment of physical insecurity, marked by the scarcity of material conditions, the resources necessary for survival acquire a high marginal utility. Nevertheless, Inglehart points out that changes in a conjuncture of individuals' living conditions are not the only ones to change value priorities. The author adds the hypothesis of socialization to the hypothesis of scarcity to explain the process of changing values. The added hypothesis assumes that socialized individuals in an environment of material insecurity embody values oriented toward material issues. Changes in these conditions do not produce immediate changes in value priorities, but they change in the next generation, which is socialized in a particular type of environment (Okado \& Ribeiro, 2017).

Post-war generations emerged with a post-materialist perspective, increasingly emphasizing non-economic issues. Classic economic issues have not disappeared, but their relative prominence has being replaced by non-economic issues on the campaign platforms of Western political parties. Thus, electoral disputes changed, showing polarization between post-materialist and authoritarian values. Income became a much weaker indicator of public policy preferences than cultural issues. In the US, for example, those opposed to abortion and same-sex marriage supported Republican candidates at the expense of Democrats. Voters moved from class-based polarization to values-based polarization.

However, recent studies, such as that developed by Inglehart and Norris (2017), have supported the idea of a traditional reaction to the postmaterialist values, which helps to explain the rise of conservative and authoritarian politicians in different parts of the world. Recent economic and moral changes have led to a reaction from conservative segments of society. Also, the exponential income reduction and increase unemployment levels, i.e., the decline in conditions of survival and existential security, possibly affected the way societies integrate differences, the individuals' political behavior, and confidence in democratic institutions. Therefore, a favorable context regarding the economy and security increases tolerance for minorities, whereas recession and insecurity have the opposite effect: they encourage authoritarianism as people look for leadership that rejects outsiders and political minorities.

Also, the decline in conditions of survival and existential security may have affected the way societies integrate differences, the individuals' economic behavior, and confidence in democratic institutions. These factors, added to the reaction against cultural change in the face of the erosion of traditional family values, may have fueled support for populist authoritarian phenomena such as Brexit, the emergence of the French National Front, and the election of Donald Trump in the United States (Inglehart \& Norris, 2017).

In the period immediately before and during the 2018 presidential election, the Brazilian economy registered a recession that affected survival conditions. The economic recession started to be felt by Brazilians in 2015 with a negative variation in GDP and a drop in household consumption. This context impacted the labor market by reducing employment levels and increasing the number of people working informally. There was also an increase in extreme poverty in the country: in 2017, more than 15 million people were below the poverty line, which was an increase of $0.8 \%$ compared to 2016 (Instituto Brasileiro de Geografia e Estatística [IBGE], 2018).

In addition to the economic scenario, data on the importance of some values for Brazilians recorded in the World Values Survey of 2018 are worth mentioning when discussing the 2018 presidential election. According to the survey, religion was considered "very important" for $45.1 \%$ and "not at all important" for $4.7 \%$ of respondents. The item "respecting authority" was considered as something "good" for $70.5 \%$ and "bad" for $6.1 \%$ of respondents. As for the importance of family, $85.3 \%$ of respondents considered it "very important" while $0.4 \%$ as "not at all important." Homosexuality was considered as "never justifiable" for $29.2 \%$ and as "always justifiable" for $18.7 \%$ of respondents. Finally, euthanasia was considered "never justifiable" for $55.4 \%$ and "always justifiable" for $10.3 \%$, and abortion was considered "never justifiable" for $64.1 \%$ and "always justifiable" for $4.7 \%$ of respondents.

The Latinobarometer survey conducted in 2018 indicated that the Brazilian institution with the highest level of trust was the Church, with $45.8 \%$ of respondents saying they have "a lot of confidence," $26.8 \%$ "some confidence," $17.5 \%$ "little confidence," and 9.4\% "no confidence at all." Brazil has always been marked by having a large Christian religious population, with a growing number of Evangelicals - from more than $15.41 \%$ in 2000 to $22.16 \%$ in 2010 (IBGE, 2010). Data from the 2010 IBGE Demographic Census showed that Catholics and Evangelicals represent $86.78 \%$ of the Brazilian population. Also, the 2018 Latinobarometer estimated that Evangelicals represented approximately $26 \%$ of the Brazilian population.

The theoretical framework and the collected secondary data support the hypothesis that Bolsonaro's electoral 
competition strategy was based on traditional moral values in terms of content, although the Brazilian economic scenario justified the salience of the topic economy and survival values in the electoral agenda. As for the form, the campaign's communication strategy was developed primarily via social media, particularly the microblogging platform Twitter. This technological instrument allowed reverberating the candidate's values and positions that would not gain space in mass media. Therefore, this study assumes that Jair Bolsonaro's election in Brazil was part of a phenomenon that has led the far-right to power in different countries, based on a shift toward traditional moral values.

Values have acquired an increasingly important dimension in people's political behavior. Therefore, as expected, values gained a special place in the candidates' political communication strategy. In this sense, it is crucial for scientific research to identify the values disseminated by candidates in their electoral campaigns.

The use of Twitter has been growing exponentially in Brazil in recent years (Ideal marketing, 2018), and the platform was widely used during the 2018 Brazilian presidential election. As a marketing tool, it is already the second most used platform in the country, and 70\% of internet users interviewed in a survey created by Twitter Brazil in 2018 (Brasil Econômico, 2018) claimed to use the microblog as a source of political information, which makes it an important political and electoral marketing resource.

During the 2018 Brazilian presidential election, Jair Bolsonaro (running for the Social-Liberal Party - PSL) used Twitter intensively to disseminate messages and set his agenda of themes to form the national debate. The content comprising such an agenda is the object of this research, which seeks to analyze the cultural values that had prominence throughout the elected president's campaign on Twitter.

\section{Methods and Techniques}

This research adopted content analysis, a technique widely used in academic studies of political communication to classify and categorize contents. As a result, the researchers can identify key elements to frame the content and arrange it for comparison with other elements (Bardin, 2011; Carlomagno \& Rocha, 2016).

The units analyzed were tweets from the official Twitter account of the elected president in the 2018 Brazilian presidential election, Jair Bolsonaro. When the same tweet fell into more than one category, we adopted the quasi-sentence analysis strategy, categorizing the content that could be extracted from each of the quasi-sentences.

The empirical investigation considered the period between July 22, 2018 (when the party - PSL - held its national convention officializing Jair Bolsonaro as its presidential candidate) and October 27, 2018 (the eve of the second-round election day). Data mining was conducted by applying Computational Intelligence methods, automatically extracting data from the account @jairbolsonaro, using public API and Python Twint library. The tweets from the period were downloaded, forming a corpus of $n=809$ elements, with 471 tweets corresponding to the first electoral round and 338 to the second round.

We first conducted an exploratory data analysis, selecting tweets based on the research goals and the typology of value analysis adopted. Tweets with all types of content were considered: text, image, and sound. Videos were duly transcribed for analysis. Tweets that did not fit or extrapolated the purposes of this investigation were discarded. This material was studied in depth in previous research (Vicari \& Iasulaitis, 2019; Iasulaitis \&Vieira, 2019), and contained meta-campaign information such as promotion of the campaign's agenda, appeal to vote, attack on opponents, endorsement, and support received without valuable content.

The next step was the categorization of each unit of analysis. The typology used was based on the dimensions of cross-cultural variation created by Ronald Inglehart and Christian Welzel, which support the World Values Survey. The two dimensions are a) the survival values versus self-expression values ( $\mathrm{x}$-axis); and $\mathrm{b}$ ) traditional values versus rational-secular values (y-axis).

Traditional values highlight the importance of religion, deference to authority, maintaining order, and traditional family values. Positions based on these values also reject divorce, euthanasia, and suicide. Abortion is never justifiable. Societies based on such values possess high levels of national pride and a nationalistic outlook. Secular-rational values emphasize the opposite, placing less emphasis on religion, family traditions, and authority. The literature has described the transition from the first to the second set of values as a replacement of religion and superstition with science and bureaucracy.

Survival values emphasize economic and physical security and are linked to a relatively ethnocentric perspective and low levels of trust and tolerance. Economic and physical security is prioritized over self-expression and quality of life. The self-expression values represent a high priority of subjective well-being, individual expression, and quality of life. In these societies, the protection of freedom of expression, environmental protection practices, tolerance toward foreigners or migrants, individual sexual orientation, and gender equality are common attitudes. There are growing demands for participation in the construction of economic and political life, interpersonal trust, political moderation, 
and a shift in values in children's education, as well as an emphasis on hard work toward stimulating creativity. In theory, the transition from survival values to self-expression values mirrors the transition from industrial to post-industrial societies, welcoming democratic values.

After categorizing the tweets based on these dimensions of values, an index was calculated to compare and demonstrate the cultural variance in Jair Bolsonaro's presidential campaign:

$$
I=\frac{p v C}{t v C}
$$

Where $p v=$ present variables, $t v=$ total variables, and $\mathrm{C}=$ category

The database used and the spreadsheets resulting from the analysis are available for replication in the repository https://dataverse.harvard.edu.

For the purpose of visualizing the keywords, the software Iramuteq (R Interface for Multidimensional analysis of Texts and Questionnaire) was used to transform the textual corpus of tags into a word cloud representing the content of the analyzed tweets.

\section{Results}

Jair Bolsonaro was launched as a presidential candidate on July 22, during the national convention of the Social-Liberal Party (PSL). The Bolsonaro-Mourão ticket, respectively, a retired Brazilian Army captain - who served seven terms as federal deputy - and a retired general-was presented only on August 5, given Bolsonaro's difficulty finding a name to fill the post of vice-presidential candidate. Bolsonaro's popularity on social media, however, had been growing in previous years. In 2016, he stated that he intended to run for president at any cost "whether you like it or not." After Donald Trump's victory in the US presidential election, he asserted that "Brazil would follow the same path" in 2018. His controversial attitudes attracted national attention. For example, in an argument with federal deputy Maria do Rosário, he said she did not deserve to be raped for being "very ugly" and "not his type." In addition, when declaring his vote in favor of the impeachment of President Dilma Rousseff in 2016, Bolsonaro invoked the memory of Colonel Brilhante Ustra, a known torturer during the Brazilian military dictatorship - a period when Rousseff was arrested and tortured.

Bolsonaro's tweets during the campaign were categorized based on the values the messages triggered. Figure 1 demonstrates the frequency Bolsonaro used each of the values considered in this research during the period analyzed.

According to the data, traditional values were the most used by the candidate throughout his election campaign $\quad(\mathrm{I}=1)$, followed by self-expression values $(I=0.52)$ and, finally, survival values $(I=0.48)$. Secular-rational values did not score. The following analysis discusses the role played by each set of values in the narrative disseminated via Twitter.

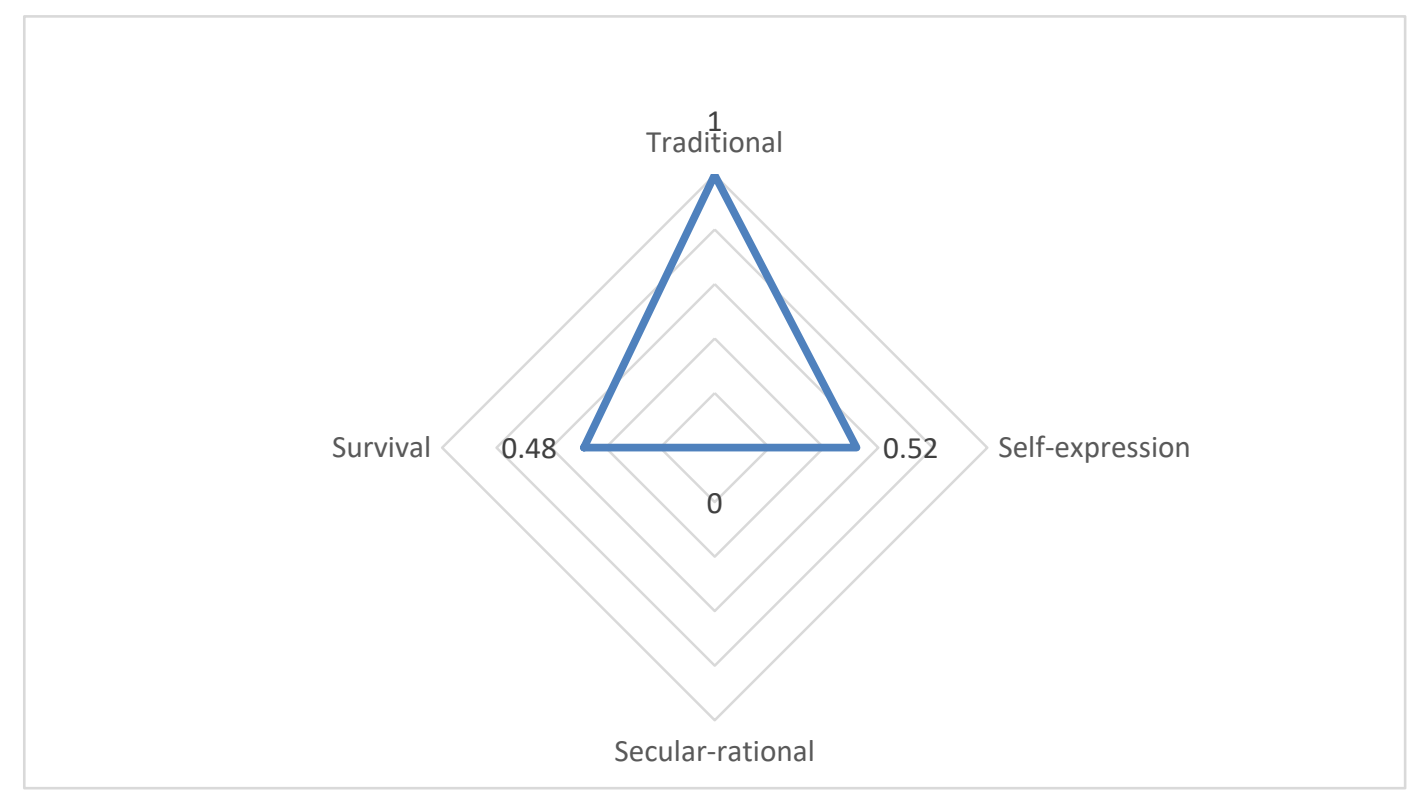

Figure 1. Indices: dimension of values 


\section{Discussion}

\subsection{Traditional Values}

Traditional values in Bolsonaro's campaign on Twitter were 38\% of the analyzed tweets (Figure 1). They were based on the ideas-forces analyzed below. The texts presented a strong defense of the traditional family in a narrative associated with the defense of private property. A tweet that illustrates this position shows an image of the candidate with his daughter, with a text saying that the family was the "fruit of our affective actions." The text continued mentioning that family and private property - which is obtained when this "fruit" is "raised honestly and in a free market economy" must both be protected, just like material goods, which cannot "be stolen, invaded or expropriated" (@jairbolsonaro, October 27, 2018).

The defense of the traditional family was also strongly based on heteronormativity. This aspect defines the standard behaviors for men and women, boys and girls, regulating the way they should be raised and educated (Matos \& Pinheiro, 2012). The then-candidate tweeted a video of his sons and daughter as children, with the text:

ATTENTION: STRONG SCENES! There is nothing wrong with teaching our children values and discipline; on the contrary, it is essential and enriching. The scolding by the press now is that I didn't dress my sons as girls, nor did I encourage the teaching of sex [sic] to children at school (@jairbolsonaro, August 23, 2018).

Based on the association between the traditional family model and heteronormativity, Bolsonaro's narrative strategy was used to combat what he called "gender ideology," or "brainwashing loaded with inversion of values" undertaken by left-wing governments. He used this topic to build the main criticisms directed at his opponent, presidential candidate Fernando Haddad, running for the Workers' Party (PT). Haddad was the Minister of Education from 2005 to 2012, and during the campaign, Bolsonaro accused him of running the ministry through an "ideological bias." According to the candidate, Haddad would have created a "gay kit" in order to disseminate the "gender ideology" in schools:

You, a father, you, a mother, do you want your child to learn sex [sic] in the classroom at the age of 6? Even [sex between] homo-affective [people]? Or straight [people], it doesn't matter. Does a father want to come home and find his son playing with a doll because of the school's influence? Unfortunately, this is true. PT wanted to impose this on schools (@jairbolsonaro, October 24, 2018).

At various times Bolsonaro referred to Haddad as "the father of the gay-kit." While Haddad denied the existence of such a proposal during his time as minister, Bolsonaro continued the attack, saying that the candidate was trying to "abort the gay-kit to avoid assuming paternity [of it]" (@jairbolsonaro, October 16, 2018). In short, the problems of Brazil's education system for Bolsonaro were "the teaching of sex [sic] in schools," "gender ideology," and "ideological indoctrination in the classroom" (@jairbolsonaro, August 01, 2018).

While Bolsonaro introduced himself as a defender of the family, whose duty was to "preserve the innocence" of children (@jairbolsonaro, October 21, 2018), he built a representation of Haddad and PT as figures at the opposite pole. He built a campaign based on dichotomous pairs. Bolsonaro associated the corrosion of traditional values with the left and communism. They would be responsible for the dissemination of a set of promiscuous ideas in schools and universities. Thus, the notion of anti-communism was in the structure of the campaign's arguments. According to Bolsonaro, both the "class struggle" and the "destruction of values" would represent "a very well organized strategy to control society, and the candidate repeatedly cited Venezuela and Cuba as examples. Standing side by side with businesspeople, Bolsonaro urged the population to "free Brazil from the ideological clutches of the left" (@jairbolsonaro, October 22, 2018) and "break the machine that wants to transform us into a Venezuela" (@jairbolsonaro, October 10, 2018). "Socialism suffocates us on all sides, with the sole aim of molding us as 'little lambs.' "Venezuela's problem is not about the military; it is about communism, this despicable and murderous ideology that famously destroys everything in its path" and asserted: "May God protect us and free us from communism!" (@jairbolsonaro, August 20, 2018).

The defense of Christianity was present in the communicational strategy based on traditional values, with biblical passages and references to the Christian God, such as the verse of John 8:32, "Ye shall know the truth, and the truth shall make you free." Furthermore, the candidate assured that he would guide his actions according to Christian principles and be responsible for preserving the religion. On the other hand, he claimed that his main opponent, Fernando Haddad, "pretended to be religious" and "throws the Bible in the trash" (@jairbolsonaro, October 26, 2018).

Continuing the defense of traditional values, the candidate made the fight against abortion a central topic: "from the beginning, we are against abortion" (@jairbolsonaro, October 17, 2018). Also, he reinforced that "whenever it depends on me, proposals to allow abortion in Brazil will have my veto and Brazilian money will not fund nonprofits that promote this practice" (@jairbolsonaro, October 12, 2018), and the hashtag \#BrasilContraOAborto (Brazil against abortion) was used several times. 
The presidential candidate exalted authority in all its forms, be it the army or the military police. Bolsonaro constantly claimed his appreciation for law and order:

Every citizen, to enjoy their full rights, must obey the laws and fulfill their duties. Anyone in the national territory, even if they are not a Brazilian citizen, has inalienable rights as a human being, as well as a duty to obey the Brazilian laws (@jairbolsonaro, October 27, 2018).

We have the foundations and the right people to finally bring to our country the values printed on our green and yellow flag: Order and Progress! (@jairbolsonaro, September 18, 2018).

Bolsonaro thus constructed a narrative that he would ultimately be defending the nation by defending traditional moral values. In this sense, special emphasis was given to a strategy of linking his image to that of a nationalist candidate, built through pro-nation slogans and using patriotic symbols.

When commenting on the demonstrations for his support, he wrote that they were "pro-Brazil and they say \#PTNo" (@ jairbolsonaro, October 21, 2018), positioning the Workers' Party as a national enemy to be fought. Thus, nationalism, the central resource explored in the tweets analyzed, intended to exalt the country and associate his candidacy with a salvationist strategy. "It is not for Bolsonaro, but for Brazil." The country, in his narrative, would have been "robbed and left to rot" by previous governments.

[It is] Time to reclaim our pride of being Brazilian; to hang our green and yellow flag in our homes; to redeem our right to come and go; We are just a few steps from greatness! Brazil above everything, God above everyone! (@jairbolsonaro, October 2, 2018).

Using a nationalist discourse, the candidate called for national unity to legitimize a national project aimed at the majorities, which is evident in a video he published on October 21, 2018, in which all elements analyzed above are present: "We are the majority! We are the real Brazil!", where he expressed his contempt for the opposition and, ultimately, its elimination: "If they want to stay here, this gang will have to put themselves under the law of all of us; either they go out, or they go to jail. These red criminals will be banned from our homeland." He used the expression "end of the beach," which refers to a specific region in Brazil where people were tortured during the military dictatorship. He defended the criminalization of social movements and the classification of such activity as terrorism:

Petralhada [depreciatively referring to PT supporters], you should all go to 'the end of the beach.' You will have no space in our homeland because I will cut off all your perks! [...]. It will be a cleanup never seen in the history of Brazil. These lazy bums will have to work! The demagogy with the Brazilian people will end. You will see the institutions being recognized; you will see proud armed forces that will collaborate for Brazil's future. You, Petralhada, will have the civil and military police with legal rearguard to enforce the law. Criminals from MST [landless workers' movement], criminals from MTST [homeless workers' movement], your actions will be typified as terrorism. You will no longer terrorize [the population in] the countryside or cities. Either you fit in and submit to the laws, or go to jail together with the 'cachaceiro' [or 'drunk man,' depreciatively referring to former President Lula da Silva, who was serving time in jail at that time after a controversial trial] in [the city of ] Curitiba [...]. We love our families, we respect our children, we respect all religions. We do not want socialism; we want to be apart from dictatorships around the world. (@jairbolsonaro, October 21, 2018).

It is noteworthy that Bolsonaro's campaign did not show any post-materialist value in the dimension of secular-rational values. In the y-axis, all tweets were categorized as traditional values. The candidate understood post-materialist values that could be framed as rational-secular values as "value inversion" put forward by the left-wing. According to the narrative, these "politically correct" values would lead to a chaotic society that would justify the action of a "Mother State," operating to control people and reduce personal liberty.

\subsection{Values of Self-Expression}

A large part of the tweets that were categorized into "values of self-expression" (33\% of posts in the microblogging platform) can be evaluated as the candidate's "immunization" against controversies, where positive messages about specific niches of voters were published after Bolsonaro made negative and controversial statements/comments toward them. In this sense, the candidate praised women and the culture of the Brazilian Northeast region, disseminating messages reinforcing his commitment to increasing safety for women and the LGBT community. He also sought to build an image of being popular among black and Brazilian pardo voters to ease the weight of sexist, racist, homophobic, and xenophobic statements the candidate made in other moments of his political history or even during the 2018 elections.

In this sense, the Northeast was the Brazilian region that received the most attention from the candidate in his tweets. In one of them, he declared that "the essence of the northeastern people is one of the main beautiful forms of cultural diversity in Brazil. Thanks to these men and women, Brazil is a giant today." When criticized for opportunistic behavior, 
he replied by saying that his father-in-law is from Ceará (Brazilian state in the Northeast region) and his daughter, therefore, has origins in the region (she has "the Northeast in her blood"). After controversial statements about the population from the Northeast and social relief programs, the candidate started to defend the conditional cash transfer program Bolsa Família, promising to "support" and "expand" the program, "combat fraud," and ensure "the correct implementation." Thus, Bolsonaro sought to prepare voters for the impact of videos circulating on social media, showing him criticizing Bolsa Família and making prejudiced comments when referring to the people from the Northeast - as in an interview given to Record News in 2012, when he stated that "Bolsa Família is a lie, in the Northeast you can't get a person to work in your house," or in October 2014, when he declared: "You see girls in the Northeast, they slap their hands on their pregnant belly and say: "- there is also the birth-related social benefit. And this one [the baby] will give us a refrigerator; this one will give us a washing machine.' And then these people do not want to work!" In a live-streamed conversation in 2016, Bolsonaro said, "There is a guy from Ceará... a big head [an insult directed at northeastern people in Brazil] here by my side. Man, I think his stomach is bigger than his head."

In his tweets during the campaign, women were portrayed as "crucial in the development of our Brazil." According to the candidate's narrative, women have the inherent role of preserving family values and educating children.

He stated that, as a deputy, he presented "many bills [...] in defense of women," and tweeted that "after four men, a girl changed my life!" statement made in April 2017, when he said that after four men, he "got weak" and then he had a daughter.

In addition to trying to ease the image of being sexist, he argued that his bill 5242/13 - which considers crimes of passion as heinous crimes, regardless of their sexual nature - also aimed to protect the LGBT community. About the LGBT community, Bolsonaro challenged the data on deaths due to homophobia released in the press, saying that this community is treated "as an ideological tool." In November 2010, however, he argued that violence would be the best way to deal with deviant sexualities: "When your son starts to get a little gay, you should spank him, so he changes his behavior."

Another example of "immunizing" the audience is his tweet about racial equality: "When I was considered to be the President of the Commission on Human Rights [Chamber of Deputies] in 2014, I made it clear: if chosen, I would be 'colorblind,' everyone would be the same color! We must fight so that we are equal before the law." In April 2017, he insulted quilombolas by making a comment that, in addition to being offensive, had racist content: "I went to a quilombo in Eldorado Paulista [name of the region]. Look, the lightest Afro-descendant guy there weighed seven arrobas. They do nothing! I don't think he even serves for breeding."

In order to "immunize" voters against the proposal to end the demarcation of indigenous lands, he published a video with the caption "Indigenous from Tribo Xingu visits Jair Bolsonaro and learns about his real proposals, free from the lies made up by PT. Brazil belongs to all of us!” (@jairbolsonaro, October 26, 2018).

The candidate frequently used the strategy of attributing the negative elements related to his image concerning women, black people, indigenous people, workers, people with disabilities, and the population from the Northeast of Brazil, to fake news produced by PT. He claimed that PT was desperate because they were losing the elections, saying that the party "cowardly" disseminated lies about him: "What a crook and brazen-faced one has to be to go around saying they are a victim of fake news while scattering to the four winds that I [when he was federal deputy] voted [bills] against disabled people, that I am going to raise taxes for the poor, get rid of Bolsa Família [conditional cash transfer program], abolish maternity leave, the bonus salary, and disseminating a bunch of other lies?” (@jairbolsonaro, October 19, 2018). Bolsonaro denounced what he called an "orchestrated movement forging aggressions to harm our campaign" (@jairbolsonaro, October 11, 2018), declaring that the attempt to link his figure to Nazism would be "another of the many lies" spread about him; by equating Nazism with communism, he claimed to repudiate both. He also intended to remove the focus from his previous sexist messages, when pointing out in PT's campaign: "They talk about inequality of wages between men and women and they want to say that I'll be responsible for that, even when I am defending the equality already provided for by law. The Workers' Party governed Brazil for almost 15 years. Why did they not solve this problem?”(@jairbolsonaro, October 08, 2018).

Therefore, several tweets are categorized in this dimension of values because they reflect some sort of respect toward political minorities and tolerance for differences. However, these manifestations are used as a strategy to contrast the candidate's offensive speeches in previous situations.

Another idea-force in the post-materialist dimension of Bolsonaro's campaign was the defense of freedom of expression, especially on the Internet, "because it is about freedom of expression and it is up to people to decide what to believe, filtering and seeking information." This perspective was used to oppose mass media. According to the candidate, the large broadcast corporations defamed his image because of their "promiscuous relations" with the left-wing, manifesting attitudes "harmful to information and democracy." In several tweets, Bolsonaro accused the newspapers of 
being "side by side with those who threaten your freedom the most." For him, this was part of a "process of implementing a totalitarian state" (@jairbolsonaro, October 10, 2018). For him, the press was "infiltrated [by left-wing journalists]," and its current role consisted of "disinforming and deceiving people," "working against Brazilians": "Those who do not read the newspaper are not informed. Anyone who reads is misinformed."

He also stated that personal liberties were threatened, indicating his websites and social media accounts as safe sources of information. The candidate claimed he was subject to persecution and that there was a movement of censorship against the right-wing, launching a campaign to raise awareness of this issue using the hashtag "\#DireitaAmordaçada" (the right-wing is gagged). For him, "the essence" of his adversaries in the electoral dispute would be "to silence those who think differently," inspired by countries with authoritarian central governments (@jairbolsonaro, October 19, 2018).

In this sense, the candidate vehemently defended freedom on the Internet: "freedom on the Internet and [freedom of the] press, which we have always defended, unlike the others [other candidates] who claim they need regulation!" (@jairbolsonaro, August 09, 2018). "Contrary to what our opponents propose, WE ARE AGAINST ANY KIND OF SOCIAL CONTROL OF THE MEDIA AND INTERNET”(@jairbolsonaro, October 11, 2018).

Bolsonaro's self-expression values observed during the two rounds of the presidential campaign, therefore, indicate an image associated with some post-materialist values a) to reduce his rejection within specific groups; and b) to defend freedom of expression on the Internet.

\subsection{Survival Values}

The category "survival values" ( $29 \%$ of tweets) encompassed a set of ideas-forces specified below. For the candidate, the recovery of economic security in the country would be associated with minimum state intervention and implementation of neoliberal proposals, such as the privatization of state-owned companies, presented as the best alternatives for the countries' economic recovery and the increase in citizens' purchasing power. The presidential candidate stated he would pursue measures such as "reducing the tax burden, reducing bureaucracy, and deregulation" and added that "free market and fewer taxes is my motto in the economy!"

I committed to reducing the number of ministries, extinguishing and privatizing a large part of the existing state-owned companies. They are unnecessary expenses that must serve the population. Refusing to make deals that involve offering positions [in state-owned companies] in exchange for [political] support is already part of this objective (@jairbolsonaro, September 21, 2018).

The defense of a minimal and efficient state is based on economic freedom. In his view, this minimal state would guarantee high productivity and competition, fostering the individuals' consumption and entrepreneurship. Thus, the free market was indispensable. This set of proposals could, according to Bolsonaro, reduce the country's high unemployment rates: "Countries with more economic freedom in the world have meager unemployment rates. We will follow this course. We will create jobs like never before! [...] Brazil will be a great nation!" (@jairbolsonaro, October $25,2018)$. The candidate also proposed an administrative reform, which would include "facilitating the opening of companies, attracting investments" and "reducing and simplifying taxes" (@jairbolsonaro, October 10, 2018).

Also, in the economic aspect, the campaign was in direct opposition with the Workers' Party. For Bolsonaro, PT was responsible for the loss of confidence of investors in Brazil, causing the economic recession: "Investors do not trust Brazil, thousands of companies shut their operations due to violence, high taxes, bureaucracy, corruption, and crisis, all inherited from the PT. We will change this picture" (@jairbolsonaro, October 25, 2018). Bolsonaro suggested that PT formed a government through nominations "based on relationships with unions," leading to a "bankrupted and corrupt system"(@jairbolsonaro, October 11, 2018). He stated that candidate Fernando Haddad intended to create more taxes and increase already existing taxes.

The fight against corruption was approached in terms of survival values, as it was at the heart of the explanation for the loss of resources and for the deprivation of a considerable portion of Brazilian society. Bolsonaro mentioned several times the corruption scandals and the Operation Car-Wash - the investigation of the biggest corruption scandal in Brazil - stimulating the atmosphere of anti-PT, associating the party to "a machine of corruption and lies" (@jairbolsonaro, October 22, 2018). Former President Lula da Silva was referred to as the "corrupt inmate chief" (@jairbolsonaro, October 23, 2018), and Haddad was nicknamed "Andrade" and "puppet of the corrupt." Taking advantage of the crisis scenario, Bolsonaro sought to channel popular energy against PT, which became a "scapegoat," configuring "one of the most traditional political mechanisms to alleviate the hatred and frustrations of sections of society" (Messenberg, 2017, our translation). Stating that the taxes paid by the population were being used to finance "socialist dictatorships around the world," the candidate reinforced the image of Brazil as "a country devastated by the biggest corruption scandals in history, led by my opponent's party. His leader gives orders from jail, he is in prison for corruption" (@jairbolsonaro, 
October 23, 2018). Linking the fight against corruption to nationalism, he released images produced in the colors of the national flag containing messages such as:

We want to promote a cultural transformation in our country, where impunity, corruption, and crime will no longer be associated with our national identity. The law and the constitution will be our instruments. Justice will be independent and must accelerate the punishment of the guilty! (@jairbolsonaro, October 13, 2018).

As an equally important discursive strategy, Bolsonaro claimed there was a coordination between the left-wing parties PT and PSOL regarding the attack he suffered on September 06, 2018, while in campaign activities in the city of Juiz de Fora (MG):

Voluntary support is something that PT does not know and does not accept. They always exercise politics by buying the people's opinion. One of the former members of his support party, PSOL, tried to murder me. We are a threat to the most corrupt people in Brazil's history. Together we will rescue our country! (@jairbolsonaro, October 18, 2018).

The feeling of existential insecurity was also addressed by the candidate in his tweets: "citizens [are] hostages in their own homes," "people are trapped inside their own homes," "There is no victim of society! SOCIETY IS THE VICTIM!" (@jairbolsonaro, August 28, 2018), "We want to give back to the population the pleasure of walking down the street without fear, of living without fear. Our enemy is the crime, not the citizen!” (@jairbolsonaro, October 9, 2018).

Bolsonaro's proposals were associated with the fight against violence and crime, involving the repeal of the firearm-control legislation (Disarmament Statute) and strong messages regarding the need to intensify the police force and tighten the way lawbreakers are treated. The candidate was straightforward when introducing himself as being in favor of reducing the age of criminal responsibility, against the concessions for prisoners to leave prison on specific dates temporarily, and against disarmament. Frequently claiming that the country suffers from " 60,000 homicides a year" and "more than 50,000 women raped," in addition to reporting several cases of murdered police officers, he intended to generate collective indignation that he could use to present his position as a strong candidate, the only one capable of "firmly facing the criminals" and truly "concerned with honest people." To consolidate this position, Bolsonaro wrote that he represented a threat "to the corrupt, criminals, rapists, to schemes made up to rob from the BNDES [National Development Bank], the murderers, and those who want to destroy Brazil" (@jairbolsonaro, October 26, 2018). He added that these groups were "desperate" because they would not be left in peace in his government.

He stated that the country suffered from a "damned legacy of violence left by previous governments" (@jairbolsonaro, October 23, 2018), i.e., PT was responsible for the high crime rates in Brazil. He argued that previous governments created a "criminal structure," defined by "impunity" and the "privileging criminals." Bolsonaro did not spare adjectives to relate the Workers' Party to violence and criminality: "they affronted justice, disrespected families, and threw the country in violence and chaos" (@jairbolsonaro, October 18, 2018).

Bolsonaro published a series of images comparing his government proposals with the government proposals by Fernando Haddad, whom he referred to as "the follower of a corrupt prisoner," in an attempt to offer evidence that the opposition would not be committed to fighting violence and would even be colluding with criminals. He pointed out that, while Haddad was in favor of "police demilitarization" and the "reduction of the prison mass in Brazil through the release of inmates," he was committed to guaranteeing "zero tolerance for crime, and reduction of the age of criminal responsibility." Also, he was committed to "arresting and leaving criminals in jail, ending the possibility of progression of sentence and temporary release." The tweets below illustrate how PT was accused of being negligent regarding violence:

My opponent said he is going to fight incarceration and release criminals from jail. Our concern and priority are good people. I have always said that I prefer a jail full of criminals to a cemetery full of innocents. If space is lacking, we can build more! (@jairbolsonaro, October 9, 2018).

If you Google "minor rapes" or "minor kills," you will find hundreds of crimes of this nature in Brazil in recent years. PT and PcdoB [Brazilian communist party], and their female federal deputies, voted AGAINST the arrest of minors who rape and kill. We've always been in favor! (@jairbolsonaro, October 11, 2018).

The candidate, who used a gun as an imagery icon of his campaign to support the proposal to amend Law 10.826 that regulates the sale and possession of firearms in national territory, declared that Brazil was living a war in which "only one side can shoot." Arguments in this sense can be observed in the examples below:

About [those saying] "bullets do not solve [the problem]": Flowers do not guarantee peace. When the "saints" who repeat this slogan stop going around with their armored cars and armed security guards. Then I will start to believe in their proposals. (@ jairbolsonaro, August 30,2018).

CRIMINALS armed to the teeth shooting innocent men, women, and children [represent a problem that] can only be 
solved with a bullet. Those who do not consider this a fact ignore the very reality we live in, and this is a sign that everything will remain the same. We understand [the problem] and will seek change! (@jairbolsonaro, August 08, 2018).

The core values used in Bolsonaro's campaign can be observed based on the word cloud built from the tweets (Figure 2. Some of the most frequent words are Brazil, God, law, PT - referring to the Workers' Party, Brazilian, crime, corrupt, corruption, violence).

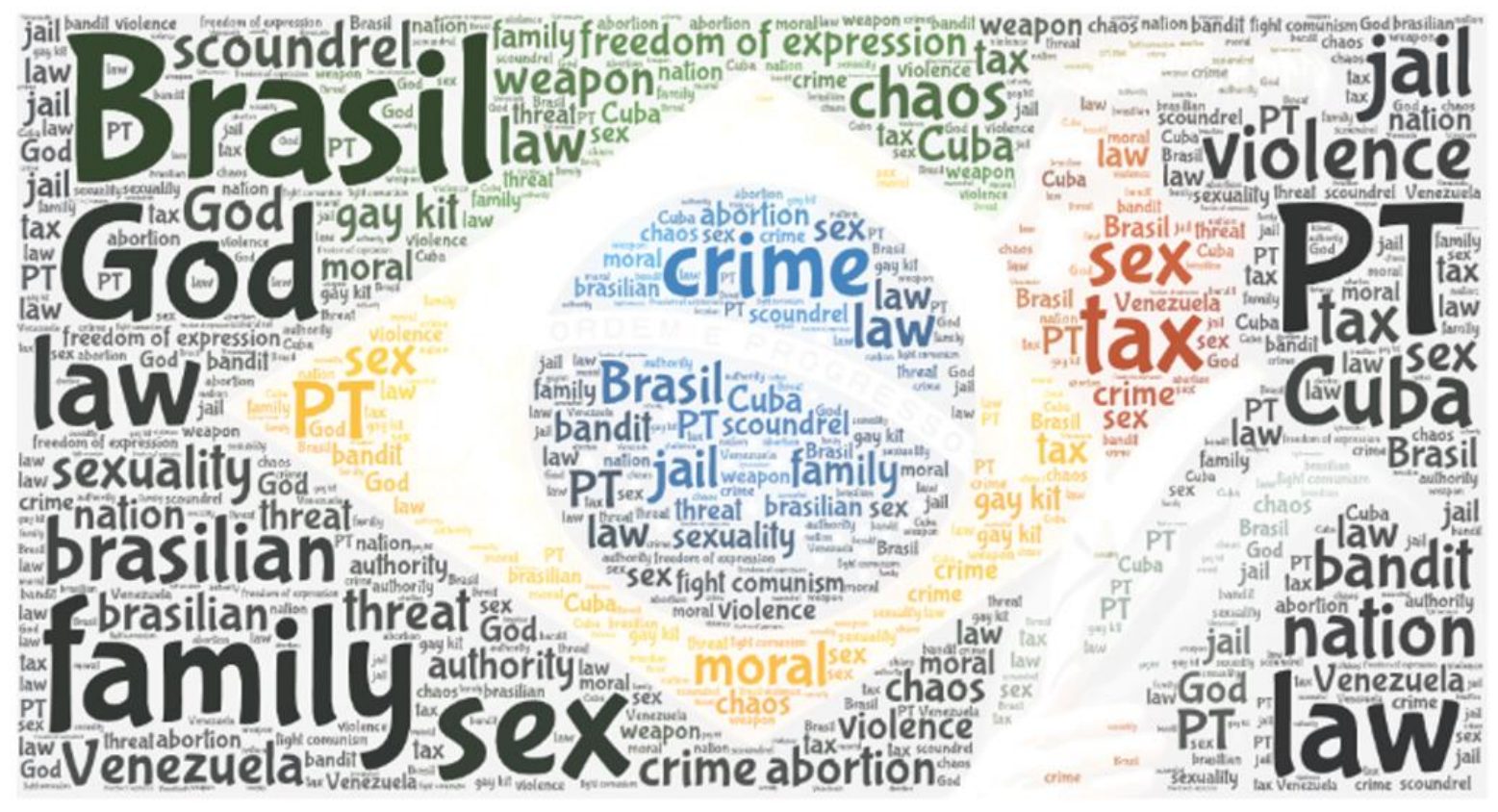

Figure 2. Word cloud of Tweets

\section{Conclusion}

This study analyzed the issues and values that gained salience in the communication strategy and electoral competition model adopted by President-elected Jair Bolsonaro's campaign on Twitter in 2018. The results obtained after categorizing the corpus of tweets in different dimensions of cultural variance showed that the candidate's campaign prioritized traditional values, emphasizing moral values, the defense of the traditional and heteronormative family, the Christian religion, and deference to all forms of authority to suppress behaviors considered immoral. These elements were coordinated from a narrative of nationalism-salvation, where the candidate - at the same time as he attributed the corrosion of traditional values to the left-wing and his main opponent, the candidate running for the Workers' Party, Fernando Haddad - assigned himself the mission of saving and rescuing the nation, which was, according to the narrative, haunted by the evils of communism and plagued by immorality.

The nationalism-salvation discourse was part of an attempt to build an environment uniting different social segments to "return the nation to the good citizens." In this sense, the campaign widely used national symbols observed particularly in the slogan "Brazil above everything, God above everyone," and the colors of the logo and campaign material alluding to the Brazilian national flag. Nationalism has historically been considered an effective weapon and "a singularly strange and powerful force that summons peoples to harness their destinies" (Bonavides, 1964, our translation). However, history shows that this "noble idea" has been misrepresented countless times by Brazilian integralism or by the totalitarianism of Hitler and Mussolini, who adopted this notion to disseminate the hatred among nations and to dominate free peoples with disastrous consequences for humanity. The same nationalist and patriotic narrative observed in Bolsonaro's campaign in 2018 can be observed in other moments in history. During the 1930s, the Nazis chartskillfully appropriated a verse of the lyrics of the German national anthem, Deutschland über alles (Germany above all), turning it into a partisan slogan to provide national identification. At the same time, Brazilian integralists, led by Plínio Salgado, were inspired by European Nazi-Fascism, and created the march in the name of "God, Fatherland, and Family."

An analysis of the pre-election national context, considering the data from the World Values Survey, allows a better understanding of the strategy adopted. The survey showed that the percentage of Brazilians who were very proud of their nationality had dropped considerably in the years before 2018. Thus, it was strategically efficient to create a 
representation of the nation that needed to be heroically rescued and protected. This representation supported the messianic narrative around Bolsonaro, who would be the bearer of a noble mission. Thus, nationalism in the elected candidate's campaign was part of a discursive persuasion strategy and not a programmatic element.

Even amid an economic crisis, Bolsonaro's campaign strategy did not highlight survival values. The index of content in the survival values dimension was much lower than the content in the dimensions of traditional values and self-expression values. As for the latter dimension, the content was restricted to advocating freedom of expression on the Internet, a strategy that complemented the candidate's narrative of being persecuted by the mass media players. It also worked as a way of "immunizing," or minimizing rejection after Bolsonaro's controversial statements about a specific electoral niche such as women, black people, non-heteronormative people, indigenous peoples, and the population from Brazil's Northeast region, and migrants.

Although the electoral scenario of 2018 pointed out the economic crisis and government accounts as central issues in politics - even being the main agenda topics in the narrative of the other candidates during the first presidential debate the topic of the economy was strategically addressed in a tangential form by Bolsonaro's campaign. As observed in the literature, periods of economic recession can trigger a decrease in tolerance, mobilizing traditional reactions toward post-materialist values and making voters more likely to support authoritarian leaders. Thus, Bolsonaro simply described his economic proposal as "deregulating and de-bureaucratizing," adding, even on the eve of his candidacy's launch, that he "did not understand economics" (Congresso Em Foco, 2018). As a result, the economic proposal defended most vigorously by the candidate was to defeat the Workers' Party, blamed for the crisis.

These elements make up a mythical plot of salvationism, where the candidate presented himself as the "messiah," bearer of a mission to rescue the nation, plagued by corruption and the deep economic crisis. He would be the only one to rescue traditional values and guarantee survival and existential security to Brazilians. Therefore, Bolsonaro presented himself as an anti-establishment actor and an agent of change - mirroring the strategies of other leaders recently elected in other countries. He took the position as the main driver of the political world, or even the people's redeemer, showing an attitude with a high degree of personification, enhanced by the communication formats granted by social media.

It was possible to identify that Bolsonaro's electoral campaign model was based on an extreme version of conservatism, which could be better classified as reactionary. His campaign focused primarily on the conservative voter, uncomfortable with the emergence of post-materialist values (such as same-sex marriage, abortion, and racial quotas). These voters are likely to accept the notion of mobilizing the state apparatus - using force, if necessary - to react to "uncomfortable changes" for the sake of returning to a nostalgic past (Teixeira, 2010). An indication of the increase in conservative voters was the growth of Evangelicals in the population, considering the characteristics of $87 \%$ of Brazilians who are Evangelicals and Christian in general. As seen in this article, the 2018 World Values Survey data show that Brazilians considered religion as "very important" and the church as the most reliable institution; the population rejected abortion and agreed with high levels of authority, as well as valuing the patriarchal nuclear family. Hence, the survey's data indicated a favorable environment for Bolsonaro's campaign to emphasize traditional values.

Bolsonaro assumed the position of an ultra-conservative candidate regarding the customs and rights of minorities, standing out from the other candidates. In general, electoral campaign models converge the strategies targeting the average voter, with a tendency to take extreme positions for differentiation purposes. Bolsonaro's campaign in 2018 focused on such positions, considering the Brazilian multiparty context, whose centrifugal incentives can lead parties to widen their ideological distinction when communicating with voters.

Hence, the study's hypothesis was confirmed since the campaign's strategy polarized post-materialist values with traditional and authoritarian values. Bolsonaro's electoral campaign strategy was based on traditional moral values regarding the content, even though the Brazilian economic scenario justified that the theme economy and survival values should be the central issues in the electoral agenda. As for the campaign's format, Bolsonaro's communication strategy was developed primarily on social media, particularly on Twitter, a technological tool that allows disseminating values and positions that would not have space in mass media.

Bolsonaro's anti-political discourses - as observed in the empirical data presented - violated the codes of political language by transgressing norms of courtesy and self-control and introducing elements of colloquial speech (Iasulaitis, Braga \& Seleghim, 2019). This was the very reason for their dissemination, primarily, on digital social networks, specifically on Twitter, a platform integrating a broad ecosystem of media, and an appropriate channel for this new format of politics that escapes the gatekeepers' control and allows widespread dissemination and repercussion. The specialized literature such as Ernst, Blassing, Engesser, Büchel and Esser (2019), demonstrates that Twitter has been prioritized by authoritarian politicians, as it makes it possible to bypass the filters of traditional mass media gatekeepers. It establishes direct communication with constituents, where candidates introduce themselves with reduced external interference, setting up their own agenda and disseminating the narratives with less influence from traditional communication 
channels.

The findings obtained in this study corroborated the theoretical framework, suggesting a renewal in authoritarian discourse, both regarding content - with emphasis on moral values and the structure of society rather than economic aspects - and in the format - with the dissemination of political positions via social media and digital platforms. The electoral success of Jair Bolsonaro's campaign in 2018 can be understood as part of a phenomenon that has led far-right leaders to power in different contexts by grounding their political message on traditional moral values.

\section{References}

Bardin, L. (2011). Análise de conteúdo. São Paulo, SP: Edições 70.

Bonavides, P. (1964). Nacionalismo, soberania e subdesenvolvimento na crise política e social do Brasil. Revista de Direito Público e Ciência Política, 7(3), 64-99. Retrieved from http://bibliotecadigital.fgv.br/ojs/index.php/rdpcp/article/view/59571

Brasil Econômico. (2018). Enquete aponta que 70\% dos internautas se informam sobre eleições pelo Twitter. Retrieved from https://tecnologia.ig.com.br/2018-08-10/eleicoes-twitter-brasil.html

Carlomagno, M., \& Rocha, L. C. (2016). Como criar e classificar categorias para fazer análise de conteúdo: uma questão metodológica. Revista Eletrônica de Ciência Política, 7(1), 173-188. https://doi.org/10.5380/recp.v7i1.45771

Congresso Em Foco. (2018). Bolsonaro diz que não entende de economia nem de feminismo. Retrieved from https://congressoemfoco.uol.com.br/eleicoes/bolsonaro-diz-que-nao-entende-de-economia-e-nem-de-feminismo/

Ernst, N., Blassing, S., Engesser, S., Büchel, F., \& Esser, F. (2019). Populists prefer social media over talk shows: an analysis of populist messages and stylistic elements across six countries. Social Media + Society, 5(1), 1-14. https://doi.org/10.1177/2056305118823358

Iasulaitis, S., \& Vieira, A. O. (2019). Quando o ataque é o programa: as estratégias de campanha de Donald Trump e de Jair Bolsonaro no Twitter. Congresso da Compolítica, 8, 1-28. Retrieved from http://compolitica.org/novo/anais-2019/

Iasulaitis, S., Braga, M. S., \& Seleghim, A. (2019). Twitter e ideologia nas eleições presidenciais de 2018. $43^{\circ}$ Encontro Anual da ANPOCS, 43, 1-25. Retrieved from http://anpocs.com/index.php/encontros/papers/43-encontro-anual-da-anpocs/st-11/st04-9/11648-twitter-e-ideologia -nas-eleicoes-presidenciais-de-2018?path=43-encontro-anual-da-anpocs/st-11/st04-9

Ideal marketing. (2018). Veja as redes sociais mais usadas no Brasil. Retrieved from https://www.idealmarketing.com.br/blog/redes-sociais-mais-usadas/

Inglehart, R. (1990). Cultural Shift in Advanced Industrial Society. Princeton, NJ: Princeton University Press. https://doi.org/10.1515/9780691186740

Inglehart, R., \& Carballo, M. (2008). ¿Existe Latinoamérica? Un análisis global de diferencias transculturales. Perfiles Latinoamericanos, 16(31), 13-38. Retrieved from http://www.scielo.org.mx/scielo.php?script=sci_arttext\&pid=S0188-76532008000100002

Inglehart, R., \& Norris, P. (2017). Trump and the populist authoritarian parties: the silent revolution in reverse. Perspectives on Politics, 15(2), 443-454. https://doi.org/10.1017/S1537592717000111

Inglehart, R., \& Welzel, C. (2005). Modernization, cultural change, and democracy: the human development sequence. New York, NY: Cambridge University Press.

Instituto Brasileiro de Geografia e Estatística. (2010). Características gerais da população, religião e pessoas com deficiência. Retrieved from https://biblioteca.ibge.gov.br/visualizacao/periodicos/94/cd_2010_religiao_deficiencia.pdf

Instituto Brasileiro de Geografia e Estatística. (2018). Síntese de indicadores sociais: uma análise das condições de vida da população brasileira. Retrieved from https://biblioteca.ibge.gov.br/visualizacao/livros/liv101629.pdf

Latinobarometer. (2018). Análisis Online. Retrieved August 18, 2021, from https://www.latinobarometro.org/latOnline.jsp

Matos, M., \& Pinheiro, M. B. (2012). Dilemas do conservadorismo político e do tradicionalismo de gênero no processo eleitoral de 2010: o eleitorado brasileiro e suas percepções. In J. E. D. Alvez, C. R. J. Pinto, \& F. Jordão (Eds.), Mulheres nas eleições 2010 (pp. 47-89). Rio de Janeiro, RJ: ABCP/Secretaria de Políticas para as Mulheres.

Messenberg, D. (2017). A direita que saiu do armário: a cosmovisão dos formadores de opinião dos manifestantes de direita brasileiros. Revista Sociedade e Estado, 32(3), 621-647. https://doi.org/10.1590/s0102-69922017.3203004 
Moreno, A., \& Carballo, M. (2013). Introducción: el estudio de los valores en América Latina. In M. Carballo, \& A. Moreno (Eds.), El cambio de valores en América Latina: hallazgos de la encuesta mundial de valores (pp. 9-17). México: Centro de Estudios Sociales y de Opinión Pública.

Okado, L. T. A., \& Ribeiro, E. A. (2017). Mudança de valores em países latino-americanos: comparando os índices de pós-materialismo e valores emancipatórios. Revista Brasileira de Ciência Política, 24, 7-48. https://doi.org/10.1590/0103-335220172401

Robertson, D. B. (1976). A theory of party competition. London, UK: Wiley.

Teixeira, C. G. P. (2010). O pensamento neoconservador em política externa dos EUA. São Paulo, SP: Editora Unesp.

Vicari, I., \& Iasulaitis, S. (2019). O nacionalismo como estratégia discursiva na campanha presidencial de Jair Bolsonaro. Semana de Pós-Graduação em Ciências Sociais, 18, 456-476. Retrieved from https://www.fclar.unesp.br/\#!/pos-graduacao/stricto-sensu/sociologia/eventos/xviii-semana-de-pos-graduacao-em-c iencias-sociais/anais-e-resumo/

World Values Survey. (2018). World Values Survey Wave 7: 2017-2020. Retrieved August 18, 2021, from https://www.worldvaluessurvey.org/WVSOnline.jsp

\section{Notes}

Note 1. This research was funded by the São Paulo Research Foundation (FAPESP), process 2020/09292-8.

\section{Copyrights}

Copyright for this article is retained by the author(s), with first publication rights granted to the journal.

This is an open-access article distributed under the terms and conditions of the Creative Commons Attribution license which permits unrestricted use, distribution, and reproduction in any medium, provided the original work is properly cited. 